\title{
Etanercept protects remote organ damage in a rat model of thermal injury
}

\author{
Özer Şehirli', Burcu Ünlü2, Şule Çetinel ${ }^{3}$, Şermin Tetik ${ }^{4}$, Emre Şener ${ }^{5}$, Göksel Şener ${ }^{1}$
}

ABSTRACT: Thermal injury may lead to systemic inflammatory response, and multiple organ failure. This study was designed to determine the possible protective effect of etanercept treatment against oxidative damage in the lung tissue induced by burn injury. Under ether anaesthesia, the shaved dorsum of rats was exposed to a $90^{\circ} \mathrm{C}$ bath for $10 \mathrm{~s}$ to induce burn injury. Etanercept $(1 \mathrm{mg} / \mathrm{kg})$ or saline was administered intraperitoneally immediately after and at 24th hour burn injury. Rats were decapitated at $6 \mathrm{~h}$ and $48 \mathrm{~h}$ following burn injury and trunk blood was collected to assay pro-inflammatory cytokines (TNF- $\alpha$ and IL-1 $\beta$ ), lactate dehydrogenase (LDH) activity. In order to evaluate the presence of oxidant injury lung tissue samples were taken for the determination of malondialdehyde (MDA) and glutathione levels, myelopreoxidase (MPO) and $\mathrm{Na}+-\mathrm{K}+$ ATPase activities. Tissues were also examined microscopically. Severe skin scald injury (30\% of total body surface area) caused a significant decrease in GSH level and $\mathrm{Na}+-\mathrm{K}+$ ATPase activity, which was accompanied with significant increases in MDA level, MPO activity. Similarly, serum TNF- $\alpha$, IL-1 $\beta$ and LDH were elevated in the burn group as compared to control group. On the other hand, etanercept treatment reversed all these biochemical indices, as well as histopathological alterations, which were induced by thermal trauma. Findings of the present study suggest that etanercept possesses an anti-inflammatory effect on burn-induced pulmonary damage and may be beneficial in thermal trauma.

KEYWORDS: etanercept; burn; cytokine; myeloperoxidase; lipid peroxidation

\section{INTRODUCTION}

Despite considerable progress in the management of burn care, systemic inflammatory response syndrome, sepsis, and multiple organ failure still continue to be a leading cause of mortality and morbidity. Following thermal injury a couple of reactions starts as a chain reaction such as sequestration of polymorphonuclear leukocytes, activation of neutrophils and xanthine oxidase system, increase in the metabolism of arachidonic acid, release of free metal ions (e.g. iron) which leads to hydroxyl radical production from hydrogen peroxide via the Fenton reaction, release of inflammatory cytokines [interleukin 1, tumor necrosis factor- $\alpha$; (TNF- $\alpha)$, etc. [, platelet aggregation and other hormonal and metabolical changes (1-4).

The release of proinflammatory cytokines plays an important role in the development of immunosuppression which predisposes patients to sepsis and multiple organ failure $(5,6)$. Normal- ly, TNF- $\alpha$ and other proinflammatory cytokines are maintained in balance by anti-inflammatory factors while this balance is shifted in favor of the proinflammatory cytokines in inflammatory diseases. Since TNF- $\alpha$ is believed to be the initiating cytokine that induces a cascade of secondary cytokines and humoral factors that can lead to local and systemic sequelae following burn injury, several studies have suggested that this cytokine triggered by the reactive biochemical species, may also contribute to cellular injury $(7,8)$.

TNF is a validated therapeutic target in a number of chronic immune-mediated inflammatory diseases, such as rheumatoid arthritis, ankylosing spondylitis, inflammatory bowel disease, and psoriasis with or without complicating arthritis (9). On the other hand, etanercept, a biologic inflammation modulator, acts as a competitive inhibitor of the binding of TNF- $\alpha$ to cell-surface TNF receptors and thereby inhibits TNF- $\alpha$-induced proinflammatory activity in the joints of

\section{AFFILIATIONS}

${ }^{1}$ Marmara University School of Pharmacy, Pharmacology, Istanbul, Türkiye

2 Yeditepe University, Faculty of Pharmacy, Istanbul,

Türkiye

3Marmara University School of Medicine, Histology,

Istanbul, Türkiye

4Marmara University School of Pharmacy, Biochemistry,

Istanbul, Türkiye

5 Marmara University School

of Medicine, Intern

CORRESPONDENCE

Özer Şehirli

E-mail:

ozersehirli@hotmail.com

Received:

28.06.2011

Revision:

16.08.2011

Accepted:

16.08.2011 
a)

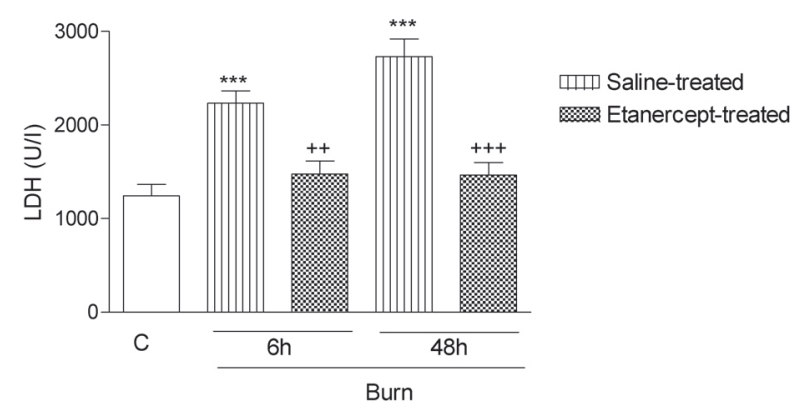

b)

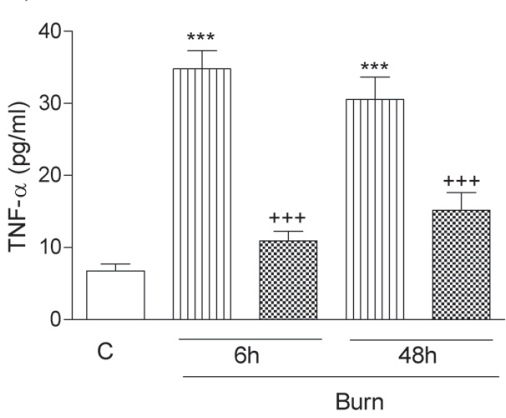

c)

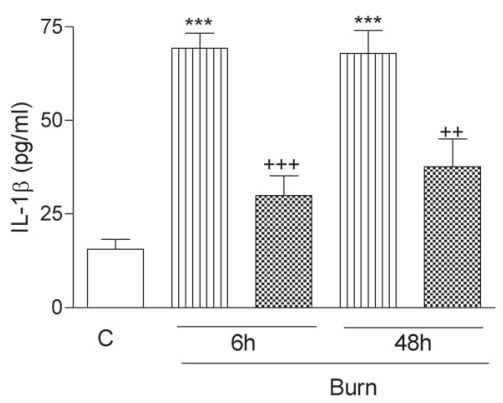

FIGURE 1. Plasma a) TNF- $\alpha$, b) IL-1 $1 \beta$, and c) Lactate dehydrogenase (LDH) levels in the control and saline -or etanercept- treated burn groups at 6 and $48 \mathrm{~h}$ following burn injury. ${ }^{* \star *}: p<0.001$ versus control group; $++: p<0.01,+++$ : $p$ $<0.001$ versus saline treated-burn group. For each group $n=8$.

RA patients. Etanercept acts as a cytokine "carrier" and TNF- $\alpha$ antagonist, rendering TNF- $\alpha$ biologically inactive, even though prolonging its half-life (10).

In the light of above findings, we investigated the potential therapeutic effect of etanercept against burn-induced lung injury using biochemical and histopathological approaches.

\section{MATERIALS AND METHODS}

\section{Animals}

Spraque Dawley rats of both sexes, weighing 200 to 300 g, were obtained from Marmara University School of Medicine Animal House. The rats were kept at a constant temperature $\left(22 \pm 1^{\circ} \mathrm{C}\right)$ with $12 \mathrm{~h}: 12 \mathrm{~h}$ light and dark cycles, were fed with standard rat chow and were fasted for $12 \mathrm{~h}$ before the experiments, but were allowed free access to water. All experimental

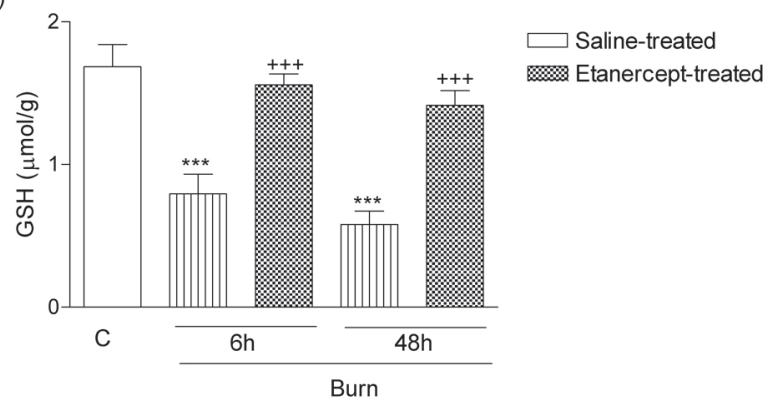

b)

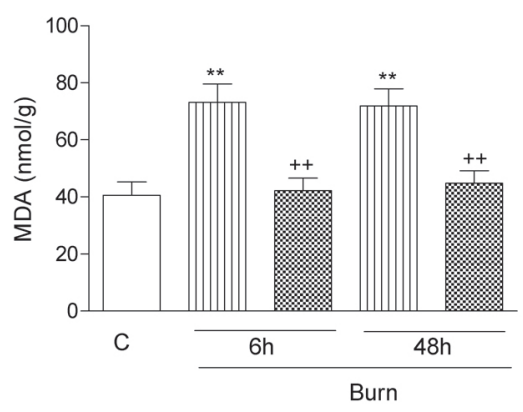

FIGURE 2. a) Glutathione (GSH), b) Malondialdehyde (MDA) levels in the lung tissues of control and saline -or etanercept- treated burn groups at 6 and $48 \mathrm{~h}$ following burn injury. ${ }^{* *}: p<0.01,{ }^{* * *}: p<0.001$ versus control group; $++: p<0.01$, $+++: p<0.001$ versus saline treated-burn group. For each group $n=8$.

protocols were approved by the Marmara University Animal Care and Use Committee.

\section{Thermal injury and experimental design}

Under brief ether anesthesia, dorsum of the rats was shaved, exposed to $90^{\circ} \mathrm{C}$ water bath for $10 \mathrm{~s}$, which resulted in a second-degree burn involving $30 \%$ of the total body surface area. This second-degree burn method was chosen to investigate the effects of etanercept on remote organ damage. All the animals were then resuscitated with physiological saline solution (10 $\mathrm{ml} / \mathrm{kg}$ subcutaneously on the hind limb). Etanercept (Wyeth Pharmaceutical, İstanbul, Turkey, $1 \mathrm{mg} / \mathrm{kg}$ ) or saline was administered intraperitoneally immediately after and at $24^{\text {th }}$ hour burn injury. In both saline- and etanercept-treated burn groups, rats were decapitated at $6 \mathrm{~h}$ and $48 \mathrm{~h}$ following burn injury. In order to rule out the effects of anesthesia, the same protocol was applied in the control group, except that the dorsum was dipped in a $25^{\circ} \mathrm{C}$ water bath for $10 \mathrm{~s}$. Each group consisted of 8 rats.

After decapitation, trunk blood was collected, to assay pro-inflammatory cytokines (TNF- $\alpha$ and IL-1 $\beta$ ), and lactate dehydrogenase (LDH) activity. In order to evaluate the presence of oxidant injury in the distant organ, lung tissue samples were taken and stored at $-80{ }^{\circ} \mathrm{C}$ for the determination of malondialdehyde (MDA) and glutathione (GSH) levels, myelopreoxidase (MPO) and $\mathrm{Na}^{+}-\mathrm{K}^{+}$ATPase activities.

\section{Cytokine assays}

Plasma levels of TNF- $\alpha$ and IL- $1 \beta$ were quantified according to the manufacturer's instructions and guidelines using enzyme- 


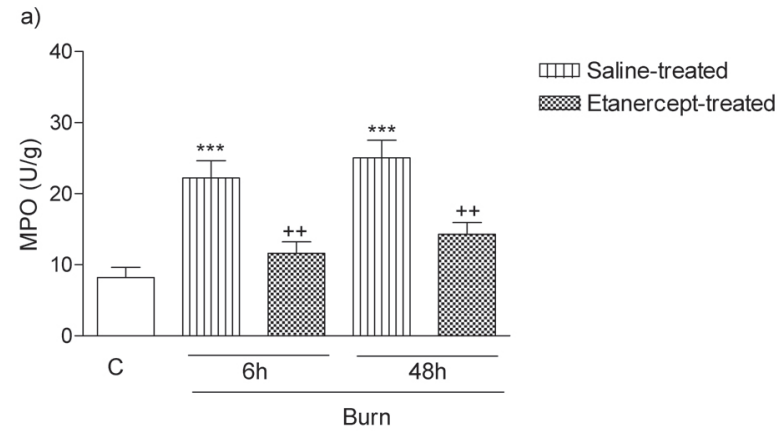

b)

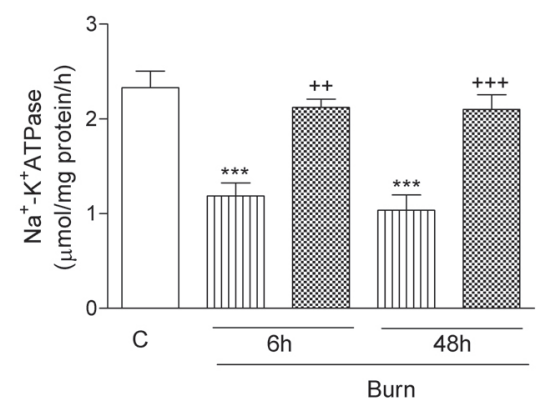

FIGURE 3. a) Myeloperoxidase (MPO), b) $\mathrm{Na}+, \mathrm{K}+$-ATPase activity in the lung tissues of control and saline -or etanercept- treated burn groups at 6 and $48 \mathrm{~h}$ following burn injury. ${ }^{* *}: p<0.001$ versus control group; $++: p<0.01,+++: p$ $<0.001$ versus saline treated-burn group. For each group $n=8$.

linked immunosorbent assay (ELISA) kits specific for the previously mentioned rat cytokines (Biosource International, Nivelles, Belgium). These particular assay kits were selected because of their high degree of sensitivity, specificity, inter- and intraassay precision, and small amount of plasma sample required to conduct the assay. Serum LDH levels (11) were determined spectrophotometrically using an automated analyzer.

\section{Malondialdehyde and glutathione assays}

Tissue samples were homogenized with ice-cold $150 \mathrm{mM} \mathrm{KCl}$ for the determination of MDA and GSH levels. The MDA levels were assayed for products of lipid peroxidation by monitoring thiobarbituric acid reactive substance formation as described previously (12). Lipid peroxidation was expressed in terms of MDA equivalents using an extinction coefficient of $1.56 \times 10^{5} \mathrm{M}^{-1} \mathrm{~cm}^{-1}$ and results are expressed as nmol MDA/g tissue. GSH measurements were performed using a modification of the Ellman procedure (13). Briefly, after centrifugation at $3000 \mathrm{rev}$. $\mathrm{min}$ for $10 \mathrm{~min}, 0.5 \mathrm{ml}$ of supernatant was added to $2 \mathrm{ml}$ of $0.3 \mathrm{~mol} / 1 \mathrm{Na}_{2} \mathrm{HPO}_{4} \cdot 2 \mathrm{H}_{2} \mathrm{O}$ solution. A $0.2 \mathrm{ml}$ solution of dithiobisnitrobenzoate $(0.4 \mathrm{mg} / \mathrm{ml} 1 \%$ sodium citrate) was added and the absorbance at $412 \mathrm{~nm}$ was measured immediately after mixing. GSH levels were calculated using an extinction coefficient of $1.36 \times 10^{4} \mathrm{M}^{-1} \mathrm{~cm}^{-1}$. Results are expressed in $\mu \mathrm{mol} \mathrm{GSH} / \mathrm{g}$ tissue.

\section{Myeloperoxidase activity}

Myeloperoxidase is an enzyme that is found predominantly in the azurophilic granules of polymorphonuclear leukocytes (PMN). Tissue MPO activity is frequently utilized to estimate tissue PMN accumulation in inflamed tissues and correlates significantly with the number of PMN determined histochemically in tissues (14). MPO activity was measured in tissues in a procedure similar to that documented by Hillegass et al. (15). Tissue samples were homogenized in $50 \mathrm{mM}$ potassium phosphate buffer (PB, pH 6.0), and centrifuged at 41,400 g (10 min); pellets were suspended in $50 \mathrm{mM}$ PB containing $0.5 \%$ hexadecyltrimethylammonium bromide (HETAB). After three freeze and thaw cycles, with sonication between cycles, the samples were centrifuged at $41,400 \mathrm{~g}$ for $10 \mathrm{~min}$. Aliquots $(0.3 \mathrm{ml})$ were added to $2.3 \mathrm{ml}$ of reaction mixture containing $50 \mathrm{mM} \mathrm{PB}$, odianisidine, and $20 \mathrm{mM} \mathrm{H} \mathrm{O}_{2}$ solution. One unit of enzyme activity was defined as the amount of MPO present that caused a change in absorbance measured at $460 \mathrm{~nm}$ for $3 \mathrm{~min}$. MPO activity was expressed as $\mathrm{U} / \mathrm{g}$ tissue.

\section{$\mathrm{Na}^{+}-\mathrm{K}^{+}-$ATPase activity}

Measurement of $\mathrm{Na}^{+}-\mathrm{K}^{+}$ATPase activity is based on the measurement of inorganic phosphate released by ATP hydolysis during incubation of homogenates with an appropriate medium containing $3 \mathrm{mM}$ ATP as a substrate. The total ATPase activity was determined in the presence of $100 \mathrm{mM} \mathrm{NaCl}, 5 \mathrm{mM}$ $\mathrm{KCl}, 6 \mathrm{mM} \mathrm{MgCl}$, $0.1 \mathrm{mM}$ EDTA, $30 \mathrm{mM}$ Tris $\mathrm{HCl}$ (pH 7.4), while the $\mathrm{Mg}^{2+}$-ATPase activity was determined in the presence of $1 \mathrm{mM}$ ouabain. The difference between the total and the $\mathrm{Mg}^{2+}$-ATPase activities was taken as a measure of the $\mathrm{Na}^{+}-\mathrm{K}^{+}-$ ATPase activity $(16,17)$. The reaction was initiated with the addition of the homogenate $(0.1 \mathrm{ml})$ and a 5 -min preincubation period. at $37^{\circ} \mathrm{C}$ was allowed. Following the addition of $\mathrm{Na}_{2} \mathrm{ATP}$ and a $10-$ min re-incubation period, the reaction was terminated by the addition of ice-cold $6 \%$ perchloric acid. The mixture was then centrifuged at $3500 \mathrm{~g}$, and $\mathrm{Pi}$ in the supernatant fraction was determined by the method of Fiske and Subarrow (18). The specific activity of the enzyme was expressed as nmol Pi mg-1 protein $\mathrm{h}^{-1}$. The protein concentration of the supernatant was measured by the Lowry method (19).

\section{Histopathological analysis}

For light microscopic investigations, lung tissue specimens were fixed in $10 \%$ buffered formalin for $48 \mathrm{~h}$, dehydrated in an ascending alcohol series, and embedded in paraffin wax. Approximately $5-\mu \mathrm{m}$-thick sections were stained with hematoxylin and eosin (H\&E) for general morphology. Histological assessments were made with a photomicroscope (Olympus BX 51; Tokyo) by an experienced histologist who was unaware of the experimental groups.

\section{Statistics}

Statistical analysis was carried out using GraphPad Prism 3.0 (GraphPad Software, San Diego; CA; USA). All data were expressed as means \pm SEM. Groups of data were compared with an analysis of variance (ANOVA) followed by Tukey's multiple comparison tests. Values of $p<0.05$ were regarded as significant.

\section{RESULTS}

In the saline-treated burn groups, serum TNF- $\alpha$ and IL-1 $\beta$ levels in both early $(6 \mathrm{~h})$ and late $(48 \mathrm{~h})$ phases of the injury were significantly increased when compared to control group $(\mathrm{p}<$ 0.001) while these elevations were abolished in etanercepttreated burn groups ( $<<0.01-0.001$; Fig. $1 \mathrm{~b}$ and 1c). Similarly, serum LDH activity showed a significant increase in the burn 

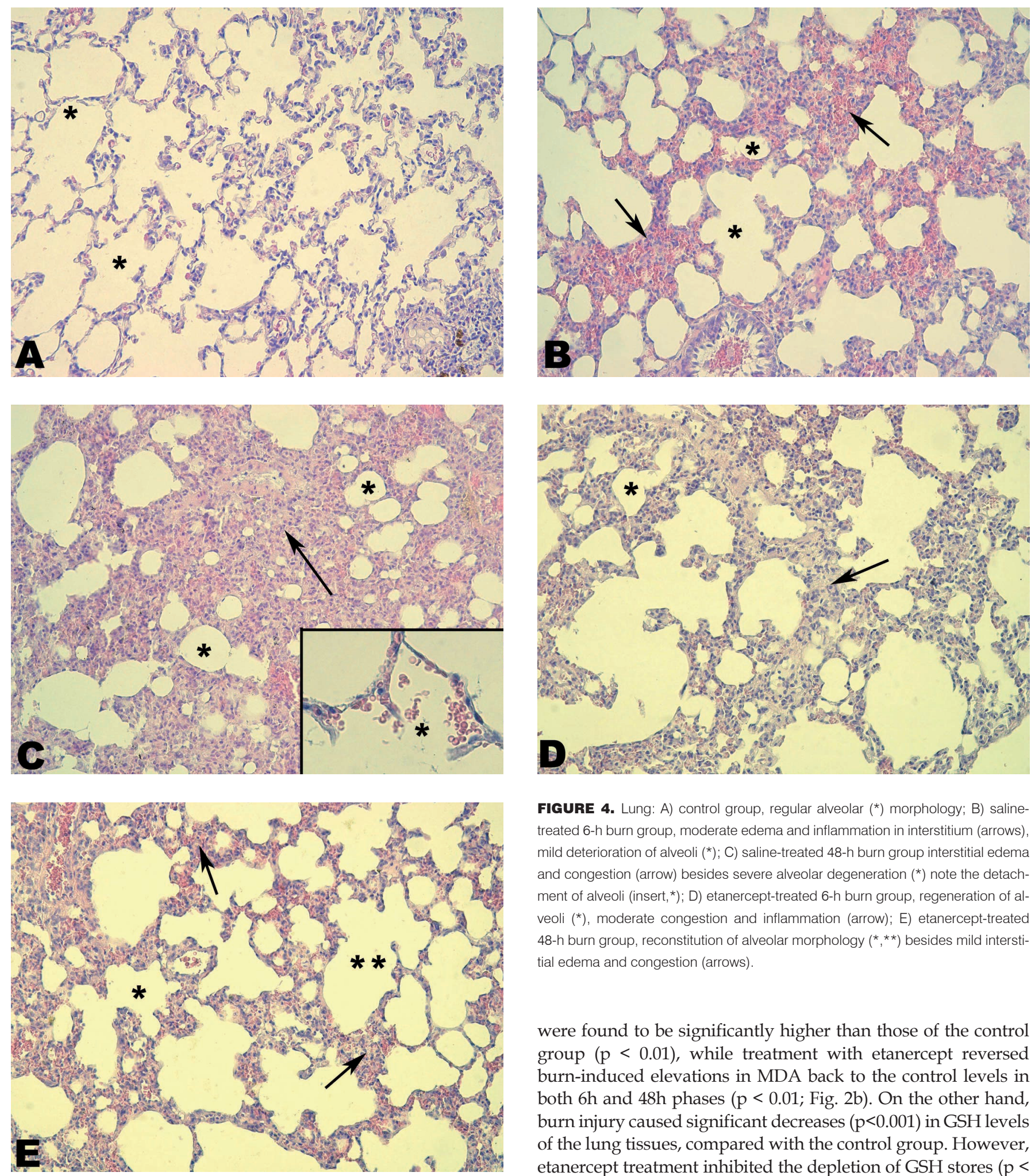

FIGURE 4. Lung: A) control group, regular alveolar (*) morphology; B) salinetreated 6-h burn group, moderate edema and inflammation in interstitium (arrows), mild deterioration of alveoli $\left({ }^{*}\right)$; C) saline-treated 48-h burn group interstitial edema and congestion (arrow) besides severe alveolar degeneration $\left(^{*}\right)$ note the detachment of alveoli (insert, ${ }^{\star}$ ); D) etanercept-treated 6-h burn group, regeneration of alveoli ${ }^{*}$ ), moderate congestion and inflammation (arrow); E) etanercept-treated 48-h burn group, reconstitution of alveolar morphology $\left({ }^{*},{ }^{* *}\right)$ besides mild interstitial edema and congestion (arrows).

were found to be significantly higher than those of the control group $(\mathrm{p}<0.01)$, while treatment with etanercept reversed burn-induced elevations in MDA back to the control levels in both $6 \mathrm{~h}$ and $48 \mathrm{~h}$ phases ( $\mathrm{p}<0.01$; Fig. $2 \mathrm{~b}$ ). On the other hand, burn injury caused significant decreases $(p<0.001)$ in GSH levels of the lung tissues, compared with the control group. However, etanercept treatment inhibited the depletion of GSH stores ( $\mathrm{p}<$ 0.001) (Fig. 2a). As an indicator of tissue neutrophil infiltration, the MPO activities were significantly higher $(\mathrm{p}<0.001)$ in lung tissues of the 6 and $48 \mathrm{~h}$ burn groups than those in the control

groups that received saline treatment $(\mathrm{p}<0.001)$, indicating generalized tissue damage, and this effect was not observed in the groups with etanercept treatment ( $p<0.01-0.001$ Fig. 1a).

Lipid peroxidation in the tissues was expressed as MDA levels. MDA levels in the lung tissues of the saline-treated burn group group, while treatment with etanercept prevented these alterations in both groups. $(\mathrm{p}<0.01$; Fig. 3a).

$\mathrm{Na}^{+}-\mathrm{K}^{+}$-ATPase activities measured in the lung tissues were reduced in the saline-treated rats $(p<0.001)$, indicating im- 
paired transport function in these tissues (Fig. 3b). However, in the etanercept-treated burned rats, the measured $\mathrm{Na}^{+}-\mathrm{K}^{+}$ATPase activities in the studied tissues were not different than those of the control rats $(\mathrm{p}<0.01-0.001)$.

Histological analysis revealed that burn trauma led to severe degeneration in lung tissue. Both 6-h and 48-hours of burn-induced groups (Fig. $4 \mathrm{~b}$ and $4 \mathrm{c}$ respectively) showed a diffuse interstitial edema and congestion more prominent in 48 hours, when compared with control group (Fig. 4a) where regular alveolar structure is present. The alveolar structure was disorganized and showed a severe detachment of alveolar cells in 48 hours, in some regions the alveoli united with each other resulting with large distented alveolar spaces. In etanercepttreated 6-h burn group, reduced interstitial edema and congestion besides maintained alveolar edema (Fig. 4d) was observed. Etanercept-treated 48-h burn group showed prominent reduction in both interstitial edema, congestion and the alveolar structure appeared to gain its integrity (Fig. 4e).

\section{DISCusSION}

Thermal trauma, one of the most common problems faced in the emergency room, triggering systemic acute inflammatory processes may cause damage to multiple organs distant from the original burn wound and may lead to multiorgan failure. As evidenced by elevations in plasma TNF- $\alpha$ and IL- $1 \beta$ levels and tissue MDA levels and MPO activity while decreased GSH levels and $\mathrm{Na}^{+}-\mathrm{K}^{+}$-ATPase activities, the current data demonstrate that thermal trauma-induced lung tissue damage is mainly an oxidative injury. Since the oxidative damage in this tissue was reversed by treatment with a TNF- $\alpha$ receptor blocker etanercept, it appears that etanercept protects against burn-induced oxidative injury of the pulmonary tissues by inhibiting the neutrophil infiltration and proinflammatory mediators.

It is known that inflammatory cytokines such as TNF- $\alpha$ and IL-1 $\beta$ induced by thermal injury trigger marked immune dysfunction and multiple organ failure (20-23). Severe burn is a stressful condition challenging all body homeostatic mechanisms, accompanied by both local and distant effects leading to intense inflammation, tissue damage, and infection. It has been considered that cytokines are important participants in the postburn pathophysiological process and at the site of tissue injury or infection, local production of proinflammatory cytokines will activate non-specific host immunity $(24,25)$. After injury, a number of cytokines are induced rapidly, including TNF- $\alpha$, interleukin-1, and interleukin-6 (26). In our study plasma TNF- $\alpha$ and IL-1 $\beta$ levels are significantly increased at both $6 \mathrm{~h}$ and $48 \mathrm{~h}$ after thermal trauma indicating the role of these cytokines in burn-induced systemic inflammation; since $\mathrm{LDH}$, an index of generalized tissue damage is also increased. On the other hand etanercept treatment decreased the cytokine levels while LDH levels were also back to control.

Although the mechanisms involved in tissue damage and immune dysfunction have yet to be elucidated, it is likely that a wide variety of mediators, including reactive oxygen species (ROS), are produced in macrophages and neutrophils after exposure to burn injury $(1,24,27)$. Activated neutrophils, lead to the formation of toxic oxygen products which further cause tissue damage. Reactive oxygen products can generate hypocholorus acid $(\mathrm{HOCl})$ in the presence of neutrophil-derived myeloperoxidase (MPO) and initiate the deactivation of antiproteases and activation of latent proteases, which lead to tissue damage (28). MPO activity is used as an indirect evidence of neutrophil infiltration (14). In our study MPO levels were increased in lung tissue indicate that neutrophil accumulation in this tissue contributes to organ injury distant from the original wound. However in the etanercept treated burn groups, MPO activities were decreased suggesting that the protective effect of this agent in burn-induced lung injury involves the inhibition of neutrophil infiltration to the tissues. Similarly in the rats with acute pancreatitis, etanercept treatment reducing MPO activity decreased caspase positive cell numbers and ameliorated acute necrotic pancreatitis (29).

Furthermore etanercept treatment in combination with dexamethasone reduces inflammation and tissue injury when administered following spinal cord trauma in rats (30). In agreement with these results, studying an in vivo canine ischemia/ reperfusion model, Gu et al (2006) demonstrated that TNF- $\alpha$ promotes post-ischemic inflammation since tissue myeloperoxidase activity was increased (31). However in this model etanercept treatment significantly decreased the enzyme activity and post-ischemic tissue injury.

A major indicator of oxidative injury is the formation of malondialdehyde (MDA), an end product of lipid peroxidation. Evidence from animal and human studies suggested that there is a correlation between the tissue MDA levels and the degree of burn complications, including shock and remote organ damage (32-35). In the present study, burn-induced increase in the lung MDA levels were prevented by etanercept treatment, suggesting that antagonism of TNF- $\alpha$ exerts a potent protective effect against lipid peroxidation. Moreover in this study reducing of MDA also contributed to preservation of tissue glutathione levels, an important antioxidant. Since cells are able to defend themselves from damaging effects of ROS by way of their antioxidant mechanisms, replenishment of GSH by etanercept treatment could be protective against burn injury.

In the current study, tissue injury as assessed by increase in MDA levels and decrease in GSH levels were accompanied by a simultaneous decrease in $\mathrm{Na}^{+}-\mathrm{K}^{+}$, ATP-ase activity, an enzyme that participates in lung fluid clearance by exerting the active transport of sodium. Since membrane-bound enzymes require phospholipids for maintenance of their activity and are susceptible to structural changes due to lipid peroxidation (36), assessment of the $\mathrm{Na}^{+} / \mathrm{K}^{+} \mathrm{ATP}$-ase activity is also used as an index for oxidant-induced tissue injury and lipid peroxidation. It has been demonstrated that oxidative lung injury induced by oleic acid is associated with increases in MDA levels and MPO activity while $\mathrm{Na}^{+} / \mathrm{K}^{+}$ATP-ase activity is decreased (37). Similarly, in acute ethanol intoxication the pump activity was also found to be decreased suggesting that oxidative stress plays a role in the maintenance of lung $\mathrm{Na}+\mathrm{K}$-ATPase, since GSH depletion seems to be a major determinant of this effect (38). On the other hand, in our study etanercept treatment increased the $\mathrm{Na}^{+} / \mathrm{K}^{+}$ATP-ase activity in parallel with a decrease in MDA levels. These protective effects of etanercept were also verified histologically.

TNF inhibition with etanercept has previously been shown to diminish the activity of rheumatoid arthritis (39). The anti-in- 


\section{Etanersept sıçan yanık modelinde uzak doku hasarında koruyucudur}

ÖZET: Termal yanık sistemik inflamatuar yanıta ve çoklu organ hasarına neden olur. Bu çalışmada yanığın neden olduğu akciğerdeki oksidan hasara karşı etanerseptin olası koruyucu etkilerinin incelenmesi amaçlanmıştır. Eter anestezisi altında sıçanların traş edilen sırt bölgeleri $90^{\circ} \mathrm{C}$ su banyosunda 10 saniye tutularak yanık oluşturulmuştur. Yanıktan hemen sonra ve 24 saat sonra etanersept $(1 \mathrm{mg} / \mathrm{kg})$ yada serum fizyolojik uygulaması yapılmıştır. Sıçanlar yanıktan 6 ve 48 saat sonra dekapite edilerek kan ve doku örnekleri alınmıştır. Kan örneklerinde proinflamatuar sitokinler (TNF- $\alpha$ ve IL-1 $\beta$ ) ve laktat dehidrojenaz (LDH) aktivitesi, incelenmiştir. Akciğer dokusunda oksidan hasarı değerlendirmek için malondialdehit (MDA), glutatyon (GSH) düzeyleri, myeloperoksidaz (MPO) ve Na+-K+ ATPaz aktiviteleri incelenmiştir. Dokular ayrıca histolojik olarak da değerlendirilmiştir. Derideki şiddetli yanık (vücut yüzey alanının \% 30'u) GSH düzeylerinde ve $\mathrm{Na}+-\mathrm{K}+$ ATPaz aktivitesinde anlamlı azalmaya neden olurken MDA ve MPO ise artış göstermiştir. Benzer şekilde serum TNF- $\alpha$, IL-1 $\beta$ ve LDH düzeyleri yanık grubunda kontrol grubuna göre artmıştır. Etanersept tedavisi ise tüm biyokimyasal parametrelerdeki değişimi geri çevirmiş ve histolojik olarak bulgular desteklenmiştir. Çalışmanın sonuçlarına göre etanersept yanığa bağlı pulmoner hasarda antiinflamatuar etki göstererek koruyucu olmuştur.

ANAHTAR KELIMELER: etanersept; yanık; sitokin; myeloperoksidaz; lipid peroksidasyonu

flammatory effects of etanercept is its ability to bind to TNF, preventing it from interacting with cell-surface receptors and rendering it biologically inactive. Di Paola et al demonstrated that treatment with etanercept attenuates; TNF- $\alpha$ activity, the infiltration of neutrophils, cell apoptosis, the iNOS, and nitrotyrosine formation. According to the findings, Di Paola et al suggest that interventions which may reduce the generation of TNF- $\alpha$, may be useful in conditions associated with local or systemic inflammation (40).

In our study we assessed the benefit of etanercept treatment in thermal trauma and results demonstrate for the first time that inhibition of proinflammatory pathways depressed the accumulation of neutrophils in the lung tissues, which cause concomitant decrease in lipid peroxidation and increase the antioxidant GSH level. Thus, etanercept merits consideration as a potential therapeutic agent for restoring organ damage following thermal trauma.

\section{ACKNOWLEDGMENTS}

The authors are grateful to Wyeth Pharmaceutical for supplying the etanercept.

\section{REFERENCES}

1. Parihar A, Parihar MS, Milner S, Bhat S. Oxidative stress and anti-oxidative mobilization in burn injury. Burns 2008;34:6-17.

2. Damtew B, Marino JA, Fratianne RB, Spagnuolo PJ. Neutrophil lipoxygenase metabolism and adhesive function following acute thermal injury. J Lab Clin Med 1993;121:328-36.

3. Kataranovski M, Magić Z, Pejnović N. Early inflammatory cytokine and acute phase protein response under the stress of thermal injury in rats. Physiol Res 1999;48:47382.

4. Yamashita Y, Jeschke MG, Wolf SE. Differential expression of hepatocyte growth factor in liver, kidney, lung, and spleen following burn in rats. Cytokine 2000;12:1293-8.

5. Meakins JL. Etiology of multiple organ failure. J Trauma 1990;30:S165-8.
6. Baue AE, Durham R, Faist E. Systemic inflammatory response syndrome (SIRS), multiple organ dysfunction syndrome (MODS), multiple organ failure (MOF): are we winning the battle? Shock 1998;10:79-89).

7. Cain BS, Meldrum DR, Dinarello CA, Meng X, Joo KA, Banerjee $\mathrm{A}$, et al. Tumor necrosis factor-a and interleukin-1b synergistically depress human myocardial function. Crit Care Med 1999;27: 1309-18.

8. Giroir B, Horton JW, White DJ, McIntyre KL, Lin CQ. Inhibition of tumor necrosis factor prevents myocardial dysfunction during burn shock. Am J Physiol 1994; 267: H118-24.

9. Taylor PC. Pharmacology of TNF blockade in rheumatoid arthritis and other chronic inflammatory diseases. Curr Opin Pharmacol 2010;10:308-15.

10. Goldenberg MM. Etanercept, a novel drug for the treatment of patients with severe, active rheumatoid arthritis. Clin Ther 1999;21:75-87.

11. Martinek RG. A rapid ultraviolent spectrophotomeetric lactic dehydrogenase assay. Clin Chem Acta 1972;40:91-9.

12. Beuge JA, Aust SD. Microsomal lipid peroxidation. Methods Enzymol 1978;52:302-11.

13. Beutler E. Glutathione. In: Red blood cell metabolism. A Manuel of Biochemical Methods, Grune and Stratton, New York, NY.1975:112-14.

14. Bradley PP, Priebat DA, Christersen RD, Rothstein G. Measurement of cutaneous inflammation. Estimation of neutrophil content with an enzyme marker. J Invest Dermatol 1982;78:206-9.

15. Hillegass LM, Griswold DE, Brickson B, AlbrightsonWinslow C. Assessment of myeloperoxidase activity in whole rat kidney. J Pharmacol Methods 1990; 24: 285-95.

16. Kim YK, Lee SH, Goldinger JM, Hong SK. Effect of ethanol on organic ion transport in rabbit kidney. Toxicol Appl Pharmacol 1986;86:411-20.

17. Reading HW, Isbir $T$. The role of cation activated ATPase in transmitter release from the art iris. Q J Exp Physiol Cogn Med Sci 1980;65:105-16.

18. Fiske $\mathrm{CH}$, SubbaRow $\mathrm{Y}$. The colorimetric determination of phosphorus. J Biol Chem 1925;66:375-400. 
19. Lowry OH, Rosenbrough NJ, Farr AL, Randall RJ. Protein measurements with the folin phenol reagent. J Biol Chem 1951;193:265-75.

20. Teodorczyk-Injeyan J A, Sparkes B G, Mills G B, Peters W J, Falk R E. Impairment of T cell activation in burn patients: a possible mechanism of thermal injury induced immunosuppression. Clin Exp Immunol 1986;65:570-81.

21. Pruitt B A. Jr. Infection and the burn patient. Br JSurg 1990;77, 1081-2.

22. $\mathrm{O}^{\prime}$ Sullivan $S T$, $\mathrm{O}^{\prime}$ Connor $\mathrm{T} P$ Immunosuppression following thermal injury: the pathogenesis of immunodysfunction. Br J Plast Surg 1997; 50: 615-23.

23. Horton JW. Free radicals and lipid peroxidation mediated injury in burn trauma: the role of antioxidant therapy. Toxicology 2003;189:75-88.

24. Ravage ZB, Gomez HF, Czermak BJ, Watkins SA, Till GO. Mediators of microvascular injury in dermal burn wounds. Inflammation 1998;22:619-29.

25. Yeh FL, Lin WL, Shen HD. Changes in circulating levels of an anti-inflammatory cytokine interleukin 10 in burned patients. Burns 2000;26:454-9.

26. Wang G, Tian J, Tang H, Zhu S, Huan J, Ge S, Xia Z. (The role of Kupffer cells on the postburn production of TNFalpha, IL-1beta and IL-6 in severely scalded rats). Zhonghua Shao Shang Za Zhi. 2002;18:282-4.

27. Toklu HZ, Tunali-Akbay T, Erkanli G, Yuksel M, Ercan F, Sener, G. Silymarin, the antioxidant component of Silybum marianum, protects against burn induced oxidative skin injury. Burns 2007;33:908-16.

28. Reiter RJ, Tan DX, Manchester LC, Qi W. Biochemical reactivity of melatonin with reactive oxygen and nitrogen species. A review of the evidence. Cell Biochem Biophys 2001;34:237-56.

29. Yilmaz M, Topsakal S, Herek O, Ozmen O, Sahinduran $\mathrm{S}$, Buyukoglu T, et al. Effects of etanercept on sodium taurocholate-induced acute pancreatitis in rats. Transl Res 2009;154:241-9.

30. Genovese T, Mazzon E, Crisafulli C, Esposito E, Di Paola $\mathrm{R}$, Muià $\mathrm{C}$, et al. Combination of dexamethasone and etanercept reduces secondary damage in experimental spinal cord trauma. Neuroscience 2007;150:168-81.
31. Gu Q, Yang XP, Bonde P, DiPaula A, Fox-Talbot $K$, Becker LC. Inhibition of TNF-alpha reduces myocardial injury and proinflammatory pathways following ischemia-reperfusion in the dog. J Cardiovasc Pharmacol 2006;48:320-8.

32. Sabry A, Wafa I, El-Din AB, El-Hadidy AM, Hassan M. Early markers of renal injury in predicting outcome in thermal burn patients. Saudi J Kidney Dis Transpl 2009;20:632-8.

33. Pintaudi AM, Tesoriere L, D'Arpa N, D'Amelio L, D'Arpa D, Bongiorno A, et al. Oxidative stress after moderate to extensive burning in humans. Free Radic Res. 2000;33:139-46.

34. Sener G, Kabasakal L, Cetinel S, Contuk G, Gedik N, Yeğen BC. Leukotriene receptor blocker montelukast protects against burn-induced oxidative injury of the skin and remote organs. Burns 2005;31:587-96.

35. Sener G, Sehirli AO, Gedik N, Dülger GA. Rosiglitazone, a PPAR-gamma ligand, protects against burn-induced oxidative injury of remote organs. Burns 2007;33:587-93.

36. Koksel O, Ozdulger A, Tamer L, Cinel L, Ercil M, Degirmenci $U$, et al. Effects of caffeic acid phenethyl ester on lipopolysaccharide-induced lung injury in rats. Pulm Pharmacol Ther 2006;19:90-5.

37. Koksel O, Kaplan MB, Ozdulger A, Tamer L, Degirmenci $\mathrm{U}$, Cinel L, et al. Oleic acid-induced lung injury in rats and effects of caffeic acid phenethyl ester. Exp Lung Res 2005;31:483-96.

38. Rodrigo R, Trujillo S, Bosco C, Orellana M, Thielemann L, Araya J. Changes in $(\mathrm{Na}+\mathrm{K})$-adenosine triphosphatase activity and ultrastructure of lung and kidney associated with oxidative stress induced by acute ethanol intoxication. Chest 2002;121:589-96.

39. Furst DE. Development of TNF inhibitor therapies for the treatment of rheumatoid arthritis. Clin Exp Rheumatol 2010;28(3 Suppl 59):S5-12.

40. Di Paola R, Mazzon E, Muià C, Crisafulli C, Terrana D, Greco $S$, et al. Effects of etanercept, a tumour necrosis factor-alpha antagonist, in an experimental model of periodontitis in rats. Br J Pharmacol 2007;150:286-97. 